\title{
ETHNIC POLITICS AND ELECTORAL VIOLENCE IN NIGERIA: A STUDY OF THE SOUTH-SOUTH GEOPOLITICAL ZONE
}

\section{Gbosien Chris Sokoh ${ }^{1}$}

\begin{abstract}
The Nigerian state since political independence in 1960 has been basking in the euphoria of ethnic politics and electoral violence. Each ethnic nationality in Nigeria has its own culture, interest, aspiration, language and faith and these factors seems to affect the socio-economic and political fate of each group, make identification with the nation a problematic task and exacerbate the difficulty in attaining credible elections a true democracy in the society. Against this backdrop, this study examined the relationship and the effect of ethnic politics on electoral violence in the southsouth geopolitical zone of Nigeria. A cross sectional research designed was adopted and data was collected via a survey of six hundred (600) respondents. Data collected were analysed using simple percentages, correlation, and linear regression analysis with the aid of statistical package for social sciences (SPSS) version 23. The results of the study revealed that there is a significant relationship between ethnic politics and electoral violence in the south-south geopolitical zone of Nigeria. The study also showed that ethnic politics exerts a positive and statistically significant impact on electoral violence in the south-south geopolitical zone of Nigeria. Based on these findings, the study concludes that ethnic politics has significant influence on electoral violence in Nigeria. The study therefore recommends, among other things, that Nigerian political leaders should place Nigerian citizens at the centre of their political project without recourse to ethnic chauvinism and the acquisition of political power as a means for serving the collective interest of the citizens irrespective of their ethnic origin. This will go a long way to reduce electoral violence in Nigeria, especially in the south-south geopolitical zone.
\end{abstract}

Keywords: Nigeria, Ethnicity, Politics, Election, Violence, Democratic Consolidation.

\section{Introduction}

Ethnicity stands very tall in Nigeria's national life and has become a major factor that determine who gets what, how and when. The Nigerian state is a good example of a multi-ethnic society beset with the issues of ethnic inclination. A close look at the society reveals a range in types of social system, language, diet, tribal marks, cultures, and dressing. The Nigerian

1 Contact Gbosien Chris Sokoh; sokohgc@gmail.com, Department of Political Science, Delta State University Abraka, Delta State, Nigeria. 
diverse social structure in terms of her heterogeneity has not changed since Nigeria gained political independence. Ethnicism denotes attachments, nationalistic mind, feelings, and the level of vindictiveness demonstrated by persons or groups as a show of loyalty, obligation, solidarity, love, and the desire to propel group aspirations over and above opposing views and similar aspirations. For instance, since the late 1950s when oil was discovered in the Niger-Delta region several discordant and intolerable behaviours, especially among the political elite representing major and minor ethnic nationalities has played itself out.

In Nigeria today, identification is easier at both the ethnic and family levels. Ethnic factors have "Largely become parameters for allocation of political offices, assessment of group representation in Government, federal character principles, indigeneship and residency rights, ethno-religious conflicts and wild protest and even the tendency to win the sympathies of persons or groups, as well as, given direct and unperturbed access to Aso Rock Villa" (Erunke, 2012: 28). According to Salawu and Hassan (2011: 28), the "diversity nature of the Nigerian state has made identification with the nation a difficult task. The consequence of this is that many of the citizens may never develop a proper concept of nation. This kind of ethnic group relation signifies a negative dimension and which may mean much for the Nigerian political system". Thus, a study on the impact of ethnic politics on electoral violence seems to be highly desirable.

A great deal has been written about ethnic politics and its effect on democratic consolidation in Nigeria (Nnoli, 1978; Edoh, 2001; Osaghae, 2001; Aluko, 2003; Salawu \& Hassan, 2011; Uwakwe, 2011; Erunke, 2012; Edewor, Aluko \& Folarin, 2014; Tandu \& Etta, 2018). Despite this number of studies, no empirical studies exist on ethnic politics and electoral violence in Nigeria. To bridge this gap, this study examines the impact of ethnic political on electoral violence in Nigeria with a focus on the south-south geopolitical zone.

\section{Statement of the Problem}

The challenges occasioned by the idolisation of ethnicity cannot be overemphasised. This is evident in the many intractable conflicts in the world today that are believed to be ethnically induced. Among the numerous examples of deadly ethnic conflicts in recent times are the Hutus against Tutsi, Croats against Serb; Kurds against Iraqis; Arab against Jew; Irish against British; Bosque against Spaniard; Tamil Nadir against Sri Lankans; Ukrainians against Russians, etc. All these make the headlines every day, yet they are only the tip of the iceberg. The heterogeneous nature of groups in every nation seems to be trouble waiting to happen (Jacobs, 2012). 
In Nigeria, ethnic and cultural conflicts are rooted in the 1914 amalgamation of the Northern and Southern protectorates by the colonial administration of Lord Frederick Lugard. The amalgamation brought about the involuntary unification of culturally and historically, diverse ethnic groups, some of which had been rivals and overlapping imperialists in the pre-colonial times. For example, Benin, at the height of its power from the $15^{\text {th }}$ century had established imperial control over some states in the fringes of present-day Northern Nigeria, including Igala and Nupe-speaking areas, which by virtue of their vassalage were compelled to pay tolls and tributes as vassals to the Benin Monarch. Benin had also extended control to the South and enjoyed suzerainty over several Yoruba states including, Eko (now Lagos), Ekiti and Ondo. This overbearing influence of Benin over the Yoruba states pitted Benin against the declining Oyo Empire before British colonisation (Ajayi \& Akintoye, 1980; Ajayi \& Alagoa, 1980).

Today, the string that holds Nigeria together is getting slimmer by the day with the conflicting juxta-positioning of ethnic groups on issues that concern the survival of the nation. With the present strength of ethnic militias to fight the course of their kinsmen against perceived outsiders, Nigeria could be sunk within a twinkling of an eye. Examples include the herdsmen militancy in the Northeast, the MASSOB in the Southeast, Oodua People Congress in the Southwest, and ever-aggressive Niger Delta Militants in the South-South region of Nigeria. In addition, Ashindorbe (2018: 92) posits that "the conduct of elections in a plural society like Nigeria is often fraught with animosities, ethnic factors and violence". It is against this background that this study examines the impact of ethnic politics on electoral violence in the South-South geopolitical zone of Nigeria.

\section{Conceptual Discourse}

\section{Ethnic Politics}

The term "ethnic" originated from the Greek work "ethnos" which is translated as nation (Chambers, 449 cited in Tandu \& Etta, 2018: 115). Ethnic in the context of this study refers to people thought to be homogenous in terms of language, race, culture and having the same ancestry. Thus, the concept of ethnicity has attracted several connotations among political science scholars. This is because like another terminology employed by social scientists; the concept of ethnicity is a term that does not lend itself to easy definition. To fully understand this, a related concept like ethnic group needs to be conceptualised. According to Cohen, 1974, cited in Salawau and Hassan (2011: 28), an ethnic group is "an informal interest 
group, whose members are distinct from the members of other ethnic groups within the larger society because they share kinship, religious and linguistic ties". Ethnicity according to Osaghae (1995), is "the employment or mobilisation of ethnic identity and influence to gain advantage in situations of competition, conflict or cooperation". This definition is preferred because it identifies two issues that are central to the discussion of ethnicity. First, ethnicity is neither natural nor accidental but, it is the product of a conscious effort by social actors. Second, ethnicity is not only manifest in conflictive or competitive relations, but also in the context of cooperation. A corollary to the second point is that ethnic conflict manifest itself in various forms, including voting, community services and violence (Edewor et al., 2014: 71).

In the context of this study, ethnicity is conceptualised as a human group having distinctive religious, certain cultural traits in common; linguistic and racial that tends to cut across continental boundaries. In Nigeria, the Arthur Richard constitution of 1946 encouraged ethnicism and hinders national integration. Thus, the colonial rule engendered factionalism which resulted into ethnic nationalism. Ethnic nationalism refers to "the tendency to see one's self as a member of an ethnic group rather than as a member of a nation" (Salawu \& Hassan, 2011: 30). This manifestation of strong allegiance to ethnic group encourages primordial sentiments among Nigerians. Therefore, ethnic politics refers to the struggle among various ethnic groups for the sharing of national resources. Since 1960 to date, the political elite in Nigeria are concerned with political and socioeconomic development of their own ethnic group and not the nation as a whole. At this point, it is necessary to posits that ethnic politics breeds hate, insecurity, suspicion, tension, group agitations and socio-political uprising (Onyibor, 2016).

From whichever angle one looks at ethnicity, it is clear that the political trajectory in Nigeria since 1960 has been those of very serious ethnic arithmetic either in terms of struggle and competition for space, mobilisation of support for those in power, creation and making of artificial violence in Nigeria and even war of words. All these according to Erunke (2012: 33), have "propelled the Nigerian state into peaceful oblivion and things are really falling apart on daily basis which the centre seem not to be strong enough to forestall emerging trends of insecurity and the vociferous separatist agitations in the country. This happening is a pointer to the politics of self, egotism and sectionalism which has been part of the Nigerian project since the colonial masters left the shores of Nigeria to date". Similarly, Odeyemi (2014: 10) asserts that "the elites keep themselves in political office by playing and preying on the ignorance and the fears of the poverty stricken majority of their people. The elites use the ethnic factor to retain themselves in office as political leaders, 
directors or managers of national corporations and parastatals by making false claims of representing their ethnic groups. Even when they do not perform well in political office, they deceive the people by whipping up ethnic sentiments, raising fears and tensions of the threats that would be posed to their ethnic group if other groups should gain political ascendency". The resultant effect of ethnic politics is indifference toward national concerns.

In addition, Peil (1976) identifies three major factors responsible for the inclination of the political elites to ethnic antics. Firstly, "ethnicity may be more important to them than to people with lesser opportunities. The society is believed to function as a series of ethnic power groups and potential elite feel the need to join one of these in order to succeed. Secondly, politicians find it difficult to win votes by universalistic appeals to ideology rather communal war crises were popular and successful. Thirdly, there were many things which went wrong in the system and ethnic 'scape-goat' was a useful way of easing pressure for reform". In fact, tribalism and marginalisation by some ethnic groups is seen to be part of the mechanism through which the political élites maintain themselves in power and exercises their influence. Thus, ethnic manipulation is an attitude of political elite's behaviour. In Nigeria today, political leaders are chief proponents and purveyors of parochialism and particularistic values. They believed that a strong inclination to ethnic chauvinism would avail them of most of the opportunities they want. Also, Aluko (2003: 254) identifies the legacy of colonialism and monopoly of power by the major ethnic groups and their consequent marginalisation of the minority groups as major factors promoting ethnic nationalism in Nigeria. Indeed, colonialism left behind for Nigeria a non-hegemonic state that further aggravated the crisis of ethnicism in the country. This is succinctly captured by Osaghee (2001: 24) when he posits that:

"The pervasiveness of ethnic politics in the country is taken to be symptomatic of aggravated crisis of legitimacy that has engulfed the state, and is explained in terms of the proven efficacy of the ethnic strategy, the weakness of alternative identities and political units, the prevailing milieu of lawlessness that has enveloped the country's political landscape, and the inability of the state to act as an effective agency of distributive justice".

Another factor responsible for inclination elites to ethnic antics is called "cultural imperialism which is often described as the infiltration of western culture into the Nigerian state. According to Onyibor (2016: 7), "this is done through the use of foreign educational materials like books, films, internet and other publications and programmes from the print and electronic media which profess the Western/American attitude to life as the original and modern, and therefore, the best. The worst aspect is that 
the youth pick the negative ones that exposes and promotes selfishness, violence, immoral and individualistic attitudes. These behavioural attitude and orientations are not acceptable to most Nigerian cultures. In fact, those who live in cities today suffer from cultural confusion. They now prefer foreign goods to Nigerian made ones. The clothes they put on, the food they eat and even the value they prefer are very much foreign". Thus, a people who do not respect their culture and values are a people without identity. Ethnicism is therefore used as a tool for the determination of power shifts, agitations and counter agitations, public official responsibility, executive propaganda, resource allocation and control, blackmail, award of contracts, appointment of persons into political offices (whether one is qualified for the job or not), religious uprising, terrorism, and electoral violence among others.

\section{Electoral Violence}

Elections are central to the effective functioning of modern representative democracy. Elections serve as instrument of political choice, accountability, and mobilisation; elections according to Powell, 2000 cited in Ighodalo (2012: 165), "are the means of selecting those to represent the people in different public positions within the polity". Election is critical aspect of the democratic framework that if properly put to use, will engender political and socio-economic development. Apart from election being one of the cardinal principles of democracy, credible, free, and fair elections put the right people in government, allocate resources efficiently and manage conflicts effectively. In the views of Adeosun (2014: 7), elections in Nigeria since 1999 "have been characterised by monumental irregularities, violence and malpractices which magnitude increases with every election. Institutions of the state such as the police, the military and the electoral body (INEC) collude to manipulate the electoral process in favour of certain candidate, especially on account of ethnic nationalism". The Nigerian experience with the 2011, 2015 and 2019 general elections has shown that the political elites have not fully come to terms with the referents of elections for democratic sustenance and enduring national security. Elections have become warfare where it is a sign to lose. This dominant pattern of elections threatens to tear the nation apart and put its tenuous peace at great risk (Ighodalo, 2012; Okereka \& Okolie, 2019).

At this point, it is necessary to conceptualise electoral violence. Albert, 2007 cited in Ashindorbe (2018: 95) posits that electoral violence's are all forms of organised acts or threats - physical, psychological and structural aimed at intimidating, harming, blackmailing, delaying, or otherwise influencing and electoral process". Similarly, Balogun, 2009 
cited Ebiziem (2015: 40) defines electoral violence as "all forms of violence (Physical, psychological, administrative, legal, and structural) at different stages engaged in by participants, their supporters, and sympathizers, including security agents and election management body in the electoral process. These forms of violence take place before elections, during elections and after elections". In the same vein, Orji and Uzodi (2012: 15) affirm that electoral violence takes any of the three dimensions: physical electoral violence according to them includes "the bodily attacks on politicians or their ardent conventions, during political campaigns, during elections and when election results are released most which culminate in fatalities". Physical election violence has remained a recurring theme in Nigeria since the reintroduction of multiparty politics in 1999. The 2011 presidential election witnessed the height of physical violence with more than 800 fatalities beside properties that were destroyed mainly in the core northern states. Psychological electoral violence, manifest in the forms of climate of siege and uncertainty that is created in the psyche of citizens of what could possibly happen to them as a result of their participation in electoral process. Election seasons since 1999 are the periods of uncertainty where due to the rhetoric and utterances of politicians, a climate of fear usually envelops the polity. It is also a period when a cocktail of grievances by rival ethnic blocs are rehearsed and deployed in the public domain. Thus, it is common during preparations for general elections to see Nigerians relocate to areas considered as safe havens away from violence prone zones, and these safe havens are usually among their Kith and Kin (Ashindorbe, 2018). Structural electoral violence manifests in the forms of exclusionary or discriminatory policies and practice prevalent in the electoral process. For instance, the exorbitant fees require aspirants within a political party or parties shuts the door against candidates without the financial muscle or a money bag ready to bankroll the electoral expenses of such candidate (Orji \& Uzodi, 2012).

\section{Ethnic Politics and Electoral Violence}

Ethnic politics remains a threat to the institutionalisation of democracy in Nigeria. Among its resultant negative consequences as observed by Babangida, 2002 cited in Salawu and Hassan (2011: 32) are "wastage of enormous human and material resources in ethnically inspired violence, encounters, clashes and even battle, heightening of fragility of the economy and political process, threat to security of life and property and disinvestments of local and foreign components with continuous capital flight and loss of confidence in the economy; and increasing gaps in social relations among ethnic nationalities including structural suspicions and hate 
for one another". The current surge of political violence caused by ethnic politics in Nigeria is a very disturbing trend towards social progress and prosperity. In Nigeria, today, political violence "has become highly disruptive to social life, thereby causing divisions in families and communities as well as causing antagonisms among and within social groups. Nigerian have witnessed several cases of electoral violence in the form of assassination, bomb-blasts, intimidations, murders, and destruction of properties in time past and now on the increase. The effect of the menace in Nigeria is tending in some respects towards social disaggregation into its constituent ethnic and sub-ethnic groups divisions. Killing, harming, and intimidating persons trying to vote during elections in order to destroy ballot boxes in areas where the perpetrators lack supporters or in order to snatch ballot boxes so as to stuff them with ballot papers illegally obtained and thumb printed creates a social division in Nigeria" (Aver et al., 2013: 264). Today, social activities such as inter-marriages, sports and worship among others are often disrupted as a result of electoral violence predispose by ethnic politics.

Salawu and Hassan (2011) noted that ethnic politics increase the gap in social relationships, create suspicious and hatred among ethnic nationalities and create room for antagonisms and electoral violence. Aver et al. (2013) argued that the major cause of political violence in Nigeria is ethnic politics, which plays a major role in electoral malpractice, corruption, incidence of political thuggery, insecurity in the country and electoral violence.

Similarly, Bello (2013) argues that one major causes of electoral violence in Nigeria is ethnic political struggle. Also, Edewor et al. (2014: 70) argues that ethnicity and cultural diversity "created more conflict (political violence) and posed obstacles to unity, peaceful co-existence, progress and stable development". Ikechukwu and Onyibor (2016) argued that ethnic politics strengthens electoral violence; undermine justice, peace, security equality and development. In line with the literature review, the following research objectives and hypotheses were formulated for this study.

\section{Theoretical Framework}

The theoretical framework of analysis adopted in this study is the Marxist theory. The theory is essential because of its relative proficiency in analysing post-colonial political economy. According to this theory, the state is the product and a manifestation of the irreconcilability of class antagonisms (Lenin, 1984). According to Ekekwe (1986: 12), "the state emerged so that antagonistic groups will not consume themselves in fruitless struggle in advanced bourgeoisie states unlike in neo-colonial 
states where state are parts and parcels of class antagonisms it was supposed to moderate. Thus, post-colonial states rather than maintains or moderate economic relations; they become an instrument of exploitation, domination and intimidation of the subjects". The Nigerian state as a postcolonial state is characterised by these factors mentioned above. Like other colonial states, Nigeria lacks the capability to moderate the struggle, which is pronounced between or among the various ethnic groups and state that make up Nigeria. Hence, political, and economic imbalances exist among and between the various state and ethnic groups in Nigeria. These imbalances exist in almost every sector of the economic; hence, most people feel marginalised - a situation which predisposes various ethnic groups to endless electoral violence. Therefore, the legacy of colonialism and monopoly of power by the major ethnic groups and their consequent marginalisation of the minority groups are the major factors responsible for electoral violence in Nigeria.

\section{Objectives of the Study}

The specific objectives of this study are:

1. To examine the relationship between ethnic politics and electoral violence in the South-South geopolitical zone of Nigeria.

2. To determine the effect of ethnic politics on electoral violence in the South-South geopolitical zone of Nigeria.

\section{Hypotheses of the Study}

The following null hypotheses were formulated to guide the researcher in finding answers to the research objectives.

$\mathrm{H}_{1}$ : There is no significant relationship between ethnic politics and electoral violence in the South-South geopolitical zone of Nigeria.

$\mathrm{H}_{2}$ : Ethnic politics does not influence electoral violence in SouthSouth geopolitical zone of Nigeria.

\section{Methodology}

A cross sectional research design was adopted and data were collected via a survey of 300 respondents in the South-South geopolitical zone of Nigeria. Out of the 300 copies of the questionnaire administered, 241 were retrieved and analysed, giving a response rate of $80.33 \%$ as shown in the table below. 
Table 1. Distribution of Questionnaire and Response Rate

\begin{tabular}{|l|c|c|c|c|}
\hline S/N & South-South States & $\begin{array}{c}\text { Questionnaire } \\
\text { Distributed }\end{array}$ & $\begin{array}{c}\text { Questionnaire } \\
\text { Retrieved }\end{array}$ & $\begin{array}{c}\text { Percentage of } \\
\text { Total Retrieved }\end{array}$ \\
\hline 1. & Delta & 50 & 45 & 18 \\
\hline 2. & Edo & 50 & 44 & 14.7 \\
\hline 3. & Rivers & 50 & 37 & 12.3 \\
\hline 4. & Cross River & 50 & 40 & 13.3 \\
\hline 5. & Akwa Ibom & 50 & 43 & 14.3 \\
\hline 6. & Bayelsa & 50 & 32 & 10.7 \\
\hline 7. & Total & 300 & 241 & 80.33 \\
\hline
\end{tabular}

Source: Field Research, 2021.

The items of measurement were rated on 5-point Likert type scale which ranks respondents on a scale of 1 (strongly disagreed) to 5 (strongly agreed). Cronbach Alpha method was used to establish the internal consistency of the instrument as shown in the table below.

Table 2. Reliability Results

\begin{tabular}{|c|c|c|}
\hline Scale & No. of Items & Cronbach Alpha \\
\hline Ethnic Politics & 7 & 0.803 \\
\hline Political Violence & 9 & 0.792 \\
\hline
\end{tabular}

Source: Field Research, 2021.

The results yielded a coefficient of 0.803 and 0.792 , which satisfies the general recommended bench mark of 0.70 for the research indicators (Cronbach, 1951). The questionnaire was also validated by experts in the department of political science. Hence, the research satisfies both reliability and validity of the instrument used for the study.

Data collected were analysed using Correlation coefficient and linear regression analysis with the aid of Statistical Package for Social Sciences (SPSS) version 23. 


\section{Research Results}

Table 3. Correlation Coefficients

\begin{tabular}{|l|c|c|c|}
\hline \multicolumn{1}{|c|}{ Variables } & Ethnic Politics & Political Violence \\
\hline Ethnic Politics & $\begin{array}{c}\text { Pearson Correlation } \\
\text { Sig. (2-tailed) }\end{array}$ & 1 & $0.774^{* * *}$ \\
\hline & $\mathrm{N}$ & 241 & 0.000 \\
\hline Political Violence & $\begin{array}{c}\text { Pearson Correlation } \\
\text { Sig. (2-tailed) }\end{array}$ & $0.774^{\text {*** }}$ & 241 \\
\hline & N & 0.00 & 1 \\
\hline & & 241 & 241 \\
\hline
\end{tabular}

*** Correlation is significant at 0.05 levels (2-tailed)

Source: Field Research, 2021.

\section{Linear Regression Analysis}

Table 4. Model Summary

\begin{tabular}{|c|c|c|c|c|}
\hline Model & $\boldsymbol{R}$ & $\boldsymbol{R}^{2}$ & $A d j-\boldsymbol{R}^{2}$ & Std. Error of the Estimate \\
\hline 1 & 0.532 & 0.471 & 0.438 & 0.211 \\
\hline
\end{tabular}

a. Predictors (constant): Ethnic politics

b. Dependent variable: Political violence Source: Field Research, 2021.

Table 5. ANOVA

\begin{tabular}{|l|l|l|l|l|l|l|l|}
\hline \multicolumn{2}{|l|}{ Model } & $\begin{array}{c}\text { Sum of } \\
\text { Square }\end{array}$ & Mean & Df & F & Sig. & Rank \\
\hline 1 & Regression & 7.533 & 3.666 & 2 & 15.317 & 0.000 b & Sig. \\
\hline & Residual & 4.801 & 0.402 & 237 & & & \\
\hline & Total & 12.334 & & 239 & & & \\
\hline
\end{tabular}

a. Dependent variable: Political violence

b. Predictors (Constant): Ethnic politics

Source: Field Research, 2021. 


\section{Discussion of Results}

Table 3 shows the correlation coefficient between ethnic politics and political violence. There exists a significant positive high correlation between the independent (ethnic politics) and the dependent (political violence) variables $(r=0.774, n=241, p<0.05)$. This implies that ethnic politics has a positive and strong relationship with electoral violence in the South-South geopolitical zone of Nigeria. Therefore, the null hypothesis is rejected. The linear regression results show value of 0.471 which revealed that ethnic politics independently accounted for $47.1 \%$ of the variation in electoral violence in South-South geopolitical zone of Nigeria. The F. statistics of 15.317 revealed that the model is statistically significant at 0.05 significant levels. Therefore, the null hypothesis is rejected. Thus ethnic politics has a significant influence on electoral violence in Nigeria.

With respect to the first hypothesis, the study found that ethnic politics have strong and positive relationship with electoral violence in the South-South geopolitical zone of Nigeria. This finding is in agreement with previous studies (Salawu \& Hassan, 2011; Aver et al., 2013; Bello, 2013; Edewor et al., 2014; Ikechukwu \& Onyibor, 2016). As predicted, the linear regression analysis results show that ethnic politics has significantly explained $47.1 \%$ of variation in electoral violence in the South-South geopolitical zone of Nigeria. Thus, the study has shown that ethnic politics exerts a positive and statistically significant impact on electoral violence. This finding is in agreement with the views of Aver et al. (2013); Bello (2013); Edewor et al. (2014) and Ikechukwu and Onyibor (2016), that ethnic politics promotes political violence in Nigeria's fourth republic.

\section{Conclusion and Recommendations}

The study has revealed through its perceived findings that ethnic politics have a strong and positive relationship with electoral violence and that ethnic politics has a positive impact on electoral violence in the SouthSouth geopolitical zone of Nigeria. Based on the findings of the study, the author concludes that ethnic politics has a significant positive influence on electoral violence. From the findings and conclusion reached, the study makes the following recommendations:

1. Nigerian political leaders should place the citizens at the centre of their political project without recourse to ethnic chauvinism.

2. Nigerian political leaders should see acquisition of power as a means of serving the collective interest of the people irrespective of ethnic origin.

3. Nigeria political leaders should desist from harassing people who criticise their activities. Political victimization of people should be 
discouraged so that the government can enjoy the support across the diverse ethnic groups.

\section{REFERENCES}

Adeosin, A.B. (2014). Democracy and democratic consolidation in Nigeria fourth republic: Issues and challenges. IOSR Journal of Humanities and Social Science, 19(10): 5-10.

Aluko, M.A.O. (2003). Ethnic nationalism and the Nigerian democratic experience in the fourth republic. Anthropologist, 5(4): 11-31.

Aver, T.T., Nnorom, K.C., \& Targba, A. (2013). Political violence and its effects on social development in Nigeria. International Journal of Humanities and Social Science, 3(7): 261-266.

Bello, A.H. (2013). Causes and dynamic of political violence in Nigeria: Islamic views on the solutions. International Journal of Humanities and Social Science Invention, 2(3): $28-34$.

Ebizem, J.E. (2015). Electoral violence and sustenance of democracy in Nigeria: A critical appraisal of 2015 presidential election. Journal of Political Science and Leadership Research, 1(8): 37-51.

Edewor, P.A., Aluko, Y.A., \& Folarin, S.F. (2014). Managing ethnic and Cultural diversity for national integration in Nigeria. Developing Country Studies, 4(6): 70-76.

Edoh, T. (2001). The upsurge of ethno-religious sentiments and the future of democracy in Nigeria. Nigerian Journal of Political Administrative Studies, 1(2): 18-36.

Erunke, C.E. (2012). Ethnic question and consolidation of Nigeria democratic project: A prognosis. Being a paper submitted to the Department of Political Science, Nasarawa State University, Kefi.

Ighodalo, A. (2012). Election crisis, liberal democracy and national security in Nigeria's fourth republic. British Journal of Arts and Social Sciences, 10(2), 163-174.

Ikechukwu, M., \& Onyibor, S. (2016). National identity and crisis of integration in multiethnic Nigeria: An existentialist perspective. Open Journal of Philosophy, 6: 1-12.

Lenin, V.I. (1984). The state and revolution. Moscow: Progress Publishers.

Odeyemi, J.O. (2014). A political history of Nigeria and the crisis of Ethnicity in nationbuilding. International Journal of Developing Societies, 3: 85-101.

Okereka, O.P., \& Okolie, U.C. (2019). Election crisis, money politics and the dearth of democracy values in Nigeria: An appraisal of 2019 general election. Journal of Management Sciences, 17(5): 9-24.

Osaghae, E. (2001). Ethnic mapping project: A brief concept. Ibadan: PEFS Publishers.

Osarhae, E. (1995). Structural adjustment and ethnicity in Nigeria. Uppsala: Nordic African Institute.

Peil, M. (1976). Consensus and conflict in Africa societies: An introduction. London: Longman. 